\title{
MULTI BODY ANALYSIS OF A TURBOCHARGER SUPPORTED BY A FULLY FLOATING RING BEARING
}

\section{JIŘí KNOTEK, PAVEL NOVOTNÝ, ONDŘEJ MARŠÁLEK, PETER RAFFAI}

Institute of Automotive Engineering, Brno University of Technology, Technická 2, CZ 61669 Brno, Czech Republic Tel.: +420 541143 476, Email: knotek@iae.fme.vutbr.cz

\section{SHRNUTI}

Tento článek popisuje pokročilý nástroj pro simulaci dynamiky rotoru turbodmychadla a jeho vývoj. $V$ článku je představen hydrodynamický model ložiska založený na řešení Reynoldsovy rovnice a dále je popsáno sestavení modelu samotného rotoru. Závěrem jsou prezentovány základní výsledky analýzy a je rozebrán jejich význam.

\section{KLIĆCVÁ SLOVA: TURBODMYCHADLO, DYNAMIKA ROTORU, LOŽISKO S PLOVOUCIMM POUZDREM}

\section{ABSTRACT}

This paper describes an advanced tool for turbocharger rotor dynamics analysis and its development. The hydrodynamic model of the journal bearing based on Reynolds equation is presented. The paper also describes assembly of the turbocharger rotor model. At the end the basic results are presented and analyzed.

\section{KEYWORDS: TURBOCHARGER, ROTOR DYNAMICS, FULLY FLOATING RING BEARING}

\section{INTRODUCTION}

Demands on modern combustion engines are continuously increasing. One of the ways to meet these demands is to use a turbocharger in the design of an engine. This means that strict conditions are also required for turbochargers.

The turbocharger is quite a specific example of rotor machinery and it is really challenging to create a highly applicable turbocharger model. The validated model represents a powerful tool for engineers dealing with the development and design of turbochargers, and it can represent quite significant savings

Floating ring bearing model scheme

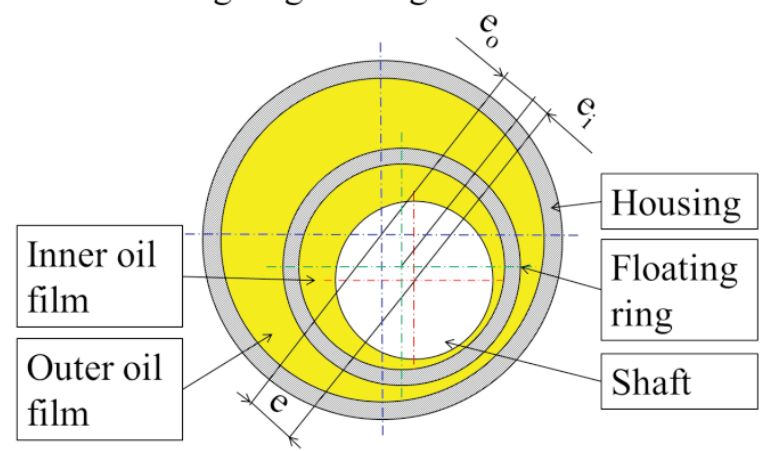

a) in time and costs related to turbocharger development and customization. Our first target for the initial modeling stage is to use knowledge and experience from the analysis of combustion engine component dynamics to develop advanced computational models of the turbocharger rotor dynamics.

At the current state of development we have reached the level of models presented worldwide [2, 3, 4], which means a turbocharger rotor with hydrodynamic bearing model and no interaction between rotor and gases.

General bearing dimensions

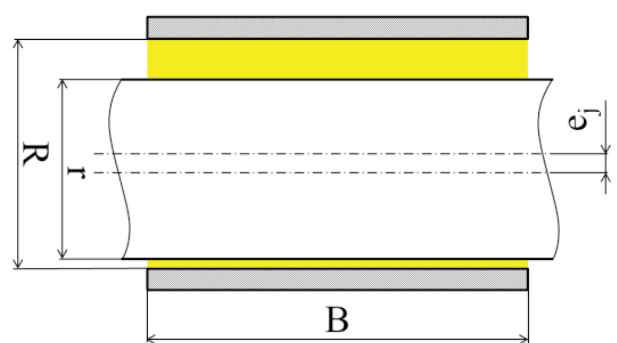

b)

FIGURE 1: General arrangement of the journal bearing model used: a) Floating ring bearing model scheme, b) General bearing dimensions OBRÁZEK 1: Situační schéma použitého modelu ložiska: a) Schéma ložiska s plovoucím pouzdrem, b) Obecné rozměry ložiska 


\section{DESCRIPTION OF THE JOURNAL BEARING MODEL}

In the design of medium and larger size turbochargers fully floating ring bearings are commonly used, represented in Figure 1a The fully floating ring bearing provides a lower friction moment and higher damping - due to two separate oil films.

For the purpose of the simulation, its characteristic two separate oil films is used - therefore, the fully floating ring bearing is represented as two separate journal bearings of specific oil properties, dimensions etc. The first journal bearing represents the oil film between the housing and the floating ring, the second one represents an oil film between the floating ring and the shaft. Therefore, three eccentricities are defined - the inner eccentricity $\left(e_{i}\right)$ is the displacement between shaft and the floating ring, the outer eccentricity $\left(e_{o}\right)$ is the displacement between floating ring and housing bore, and overall eccentricity $(e)$ is the displacement between shaft and the housing bore.

\subsection{HYDRODYNAMIC JOURNAL BEARING MODEL BACKGROUND}

Due to fact that turbocharger journal bearings don't usually operate under high eccentricity conditions, the hydrodynamic journal bearing model is used to introduce hydrodynamic forces and moments to the rotor dynamics simulation.

The theory suggested by Novotny (2009) is adopted for determination of hydrodynamic pressure profile in the oil film. The basic conception is still derived from Reynolds equation:

$\frac{\partial}{\partial x}\left(\frac{\rho h^{3}}{12 \eta} \frac{\partial p}{\partial x}\right)+\frac{\partial}{\partial y}\left(\frac{\rho h^{3}}{12 \eta} \frac{\partial p}{\partial y}\right)-\frac{\partial(u \rho h)}{\partial x}-\frac{\partial(\rho h)}{\partial t}=0$,

where $p$ is pressure, $x$ and $y$ are coordinates, $h$ is the oil film gap height, $\eta$ is the dynamic viscosity of oil, $\rho$ is the dynamic density of oil and $u$ is an effective velocity. The oil film gap is defined as:

$h=R-r+e_{j} \cdot \cos (\varphi)$,

where $R$ is the shell radius, $r$ is the journal radius, $e_{j}$ is the journal eccentricity, and $\varphi$ is the angle around the journal axis.

The hydrodynamic model of a journal bearing is introduced to the rotor dynamics simulation in MBS by sets of pre-calculated databases, which are the most important parameters entering the equations for calculating forces and moments acting on the journal bearing. Hydrodynamic databases are basically look-up tables; the dimensionless force (or moment) is determined for specific relative eccentricity and relative tilt angle in the plane of the smallest oil gap. Hydrodynamic databases are computed for a ratio $B / D$, in a specialized program developed at the Institute of Automotive Engineering. The Finite Difference Method (FDM), variable integration steps and a multi-grid strategy are used, and the system is solved using the iterative solution. The final state of the hydrodynamic databases is calculated based on determined pressure distribution by integrating across the whole bearing surface.

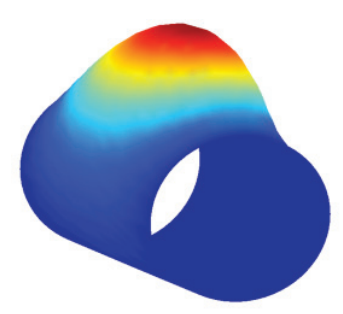

FIGURE 2: Hydrodynamic pressure profile in the bearing OBRÁZEK 2: Profil hydrodynamického tlaku v ložisku

\subsection{JOURNAL BEARING PRESUMPTIONS}

Since the journal bearing is represented in the MBS by sets of pre-calculated databases, several presumptions have to be considered to enable creation of the databases in advance. The presumptions are as followed [1]:

- the journal and bearing shell shapes are ideal cylindrical parts,

- the journal and the bearing shell are rigid bodies without any deformations, an oil gap between the journal and the shell is filled up with the oil and the gap proportions are small in comparison with journal or bearing shell proportions,

- only hydrodynamic frictions can occur,

- dynamic viscosity is constant for the whole gap volume and it is independent of local temperature and pressure,

- lubricating oil is incompressible, and

- oil flow is laminar.

\section{ASSEMBLY OF THE TURBOCHARGER MBS MODEL}

Generally, there are two possible ways to assemble the turbocharger rotor model, as shown in Figure 2. The first way, shown in Figure 3a, is to discretize the whole rotor (which includes shaft and compressor, and turbine wheels) using FE software and then perform a reduction of the FE model. Specific material characteristics have to be considered during meshing the rotor since they can't be changed later. The second way, shown in Figure 3b, is to discretize only the shaft and both wheels attached to the shaft in MBS software. This method provides several benefits - for example, for turbocharger optimization when design and material of both wheels can 


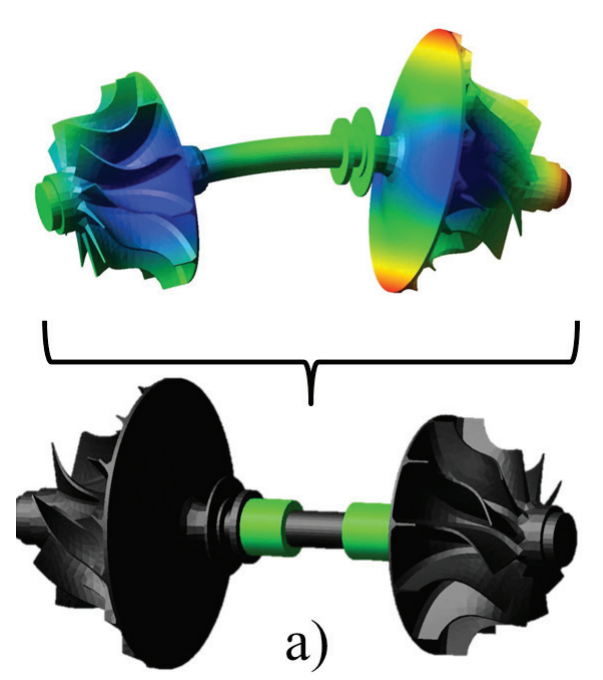

FIGURE 3: Turbocharger rotor model

OBRÁZEK 3: Model rotoru turbodmychadla

be changed easily. It is necessary to pay attention to correct assignment of moments of inertia and mass to each wheel.

As for the rotor model, for the purpose of this paper the second method (Figure 3b) has been chosen. The shaft model is considered a flexible body, and it is based on reduced Finite Element (FE) bodies. Both the turbine and compressor wheels are represented as a rigid body with mass and inertia tensor defined. Wheels are attached to the shaft with fixed joint connectors in markers coincident to the attachment nodes.

To complete the turbocharger assembly model, the housing model and rings to complete the fully floating ring bearing model have to be added. Rings can be considered rigid bodies because the forces acting on them can't perform any noticeable deformations, and due to the ring size, their contribution to overall vibration is negligible. As for the housing model, there are two ways to create a model with a rigid housing or a flexible housing. The rigid housing provides lower computational times and is sufficient for basic rotor dynamics simulations. The flexible housing is more demanding on computational time, but is useful for advanced rotor dynamics simulations, and absolutely essential for turbocharger noise and vibrations analysis. The last of the bodies needed to complete the turbocharger MBS model is an auxiliary body through which the rotor is accelerated to the desired speed. This is needed only for run-up simulation with desired angular acceleration. The rotor can also be sped up by torque applied to the turbine wheel, in which case the auxiliary body is unnecessary.

\section{SIMULATION RESULTS}

The most important simulation results can be divided into several groups:

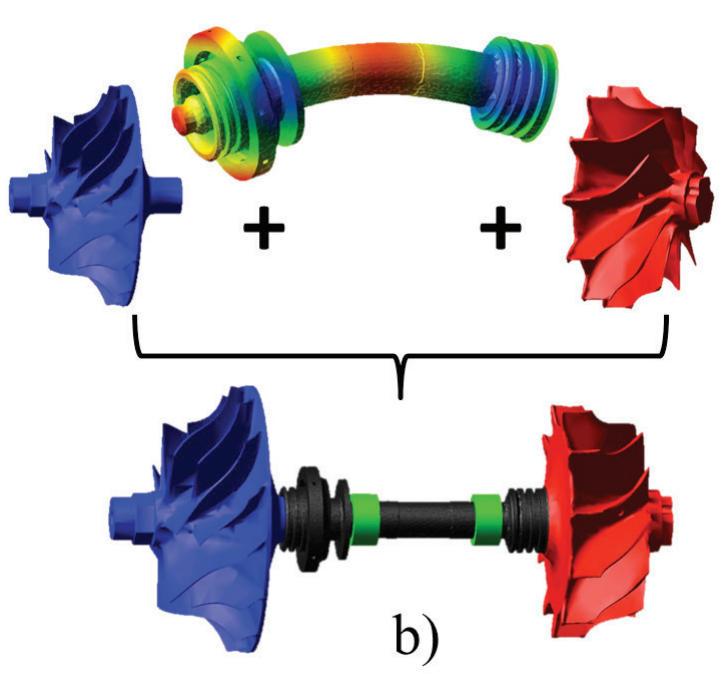

- bearing:

- parameters describing shaft and ring movements (displacement, velocity, acceleration, rotor and ring speed),

- friction results (friction moment, power loss),

- slide bearing oil film behavior (oil flow and temperature),

- reactions in the slide bearing oil film (forces and moments),

- rotor:

- wheel nose displacement, velocities and accelerations,

- shaft stress,

- torque needed for turbocharger run-up,

- housing:

- mounting points vibration and the emitting of surface noise.

The most critical parameter is wheel nose displacement because in the case of a collision the turbocharger would be seriously damaged or even destroyed. However, turbocharger design is so advanced these days that this kind of failure is rare. On the other hand, turbocharger noise and vibration, power losses and oil flow are very important parameters. Bearing parameters will always be very important because they can show us potential usage for bearings and reveal rotor stability issues.

\subsection{INITIAL CONDITIONS OF THE SIMULATION}

For better understanding of the simulation results, it is necessary to know the initial conditions. Therefore they are listed below:

1. Rotor assembly conditions:

a. shaft is positioned in the middle of the floating ring $\left(e_{i}=0\right)$,

b. floating rings are positioned in the middle of the housing bore $\left(e_{0}=0\right)$, and 
C. rotor speed is zero.

2. Loads acting on the rotor and bearing assembly (all of them are acting from the beginning of the simulation):

a. gravity acting in the vertical direction (rotor assembly axis of rotation lies in the horizontal plane),

b. oil pressure is 3.5 bar (the oil input pressure doesn't influence the rotor dynamics due to bearing model simplification, but it influences the bearing oil flow and oil warm up), and

c. rotor assembly speed increases linearly. The rotor assembly is driven and the speed is controlled through the auxiliary body and torsional spring (the rotor speed can also be increased by the torque, but from the point of view of speed control, it is better to define the rotor speed).

3. Housing conditions:

a. the housing is defined as a rigid body, and

b. housing bore misalignment is neglected.

The flexible housing model is essential for potential simulation of vibrations on the housing walls or the emitting of noise. However, in basic rotor dynamics simulation it doesn't seem to have such an impact on rotor dynamics to incorporate the flexible housing model into every simulation performed, because the bearing is quite low and so is the deformation of the housing bore. Since the displacement for the waterfall diagram is measured with respect to the static coordinate system and not the housing, even the waterfall would be very similar.

\subsection{BEARING ECCENTRICITY}

The bearing eccentricity is not as important as compressor (turbine) to housing eccentricity, but it can provide useful information about bearing load and the potential of its use. For journal bearings the relative eccentricity should range from $45 \%$ to $80 \%$. If the relative eccentricity is lower than $45 \%$, the risk

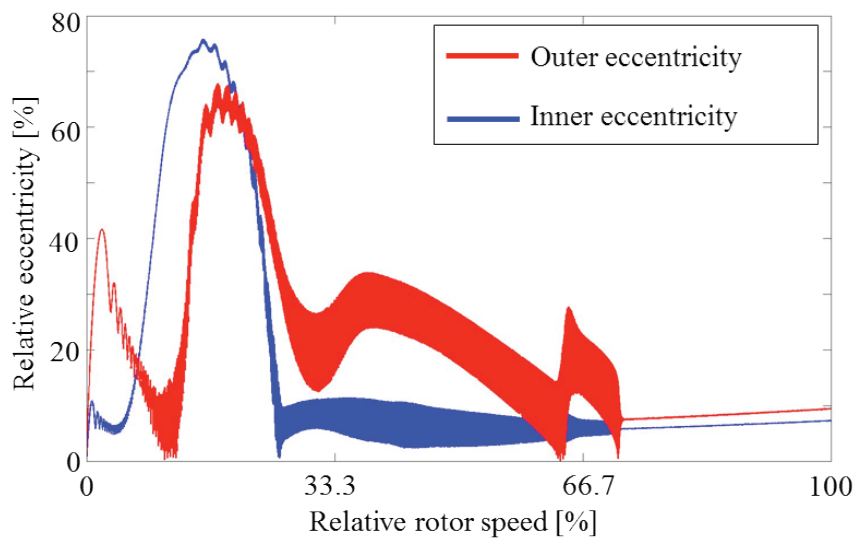

FIGURE 4: Bearing eccentricity on the compressor side OBRÁZEK 4: Ložisková excentricita na straně kompresoru of self-excited oscillation is very high; if the relative eccentricity is higher than $80 \%$, the oil film has a very low load capability. The inner and outer eccentricity in a fully floating ring bearing on the compressor side is shown in Figure 4. The highest value of inner eccentricity is approximately $75 \%$ and can be found around a relative rotor speed of $15.33 \%$. If rotor speed increases further, the inner oil film appears to be stable and there are no other peaks. The outer oil film seems to be more unstable and there are some significant peaks. The first peak is located around relative rotor speed of $18 \%$ and reaches the eccentricity of $67 \%$; the second peak is much lower; it reaches the eccentricity of only $34 \%$ and is located around the relative speed of $38 \%$.

The last peak is located around the relative rotor speed of $65.33 \%$ and reaches an eccentricity of only $28 \%$. To better understand the source of these greater eccentricities, it is very useful to create a waterfall of displacement, velocity or acceleration and to compare it with a graph of eccentricity.

\subsection{OSCILLATION FREQUENCY SPECTRUM}

To understand the rotor dynamics and to reveal the sources of oscillation, it is very useful to create a waterfall graph. A waterfall graph is essentially a 3D graph, with rotor speed located on the $x$-axis, oscillation frequency located on the $y$-axis and the magnitude of displacement on the z-axis. The displacement evaluated in this waterfall diagram is measured on the compressor wheel nose.

Figure 5 represents the frequency spectrum across the whole speed range and it enables identification of the source of rotor instabilities. It is very important to realize that although the unbalance causes the synchronous oscillation, it also stabilizes the rotor dynamics. There is still an essential need to retain unbalance and thus synchronous oscillation within limits.

The synchronous oscillation can be kept within acceptable limits by balancing the rotor properly, but the other types of oscillations come from the oil film and they can be influenced by bearing design, oil properties etc.

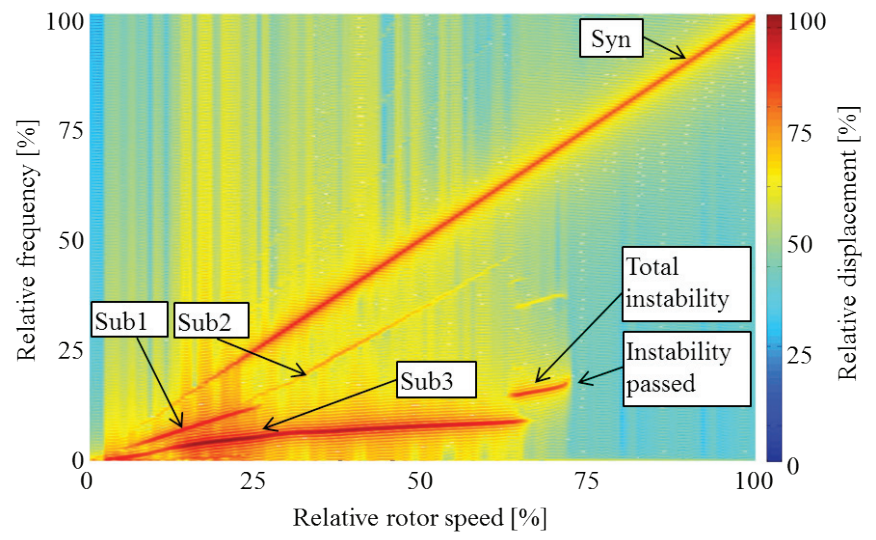

FIGURE 5: Frequency spectrum of the oscillation OBRÁZEK 5: Frekvenční spektrum vibrací 


\subsection{VERIFICATION OF THE SIMULATED RESULTS}

Verification of results is one of the basic steps in developing any computational model. In the case of turbocharger rotor dynamics, the measuring is limited due to the compact construction of a modern turbocharger.

$A$ basic parameter which is usually measured is the compressor wheel nose displacement. The displacement is measured in a two axis system and the evaluated parameter is usually the mid-point trajectory. The compressor wheel is a better choice for the purpose of the measurement because the temperatures of the housing and gas on the compressor side are significantly lower than on the turbine side.

Another parameter which can be measured is the speeds of the floating rings on both compressor and turbine side (if the turbocharger has floating ring bearings). This parameter is much more difficult to measure, and thus these measurement data are quite rare.

Other possible measuring parameters are: the noise emitted by the turbocharger (mainly housing walls) and housing vibration. The model suggested in this paper has yet to be verified, but of the parameters listed above, the compressor nose displacement will certainly be measured. If the housing design provides enough space, the floating ring speeds may also be measured for both bearings. As for noise and vibration measurement, since the suggested model allows only for vibration analysis so far, only the vibrations of the housing may be measured.

Even though the model as a whole is yet to be verified, its main individual parts (bearing model, shaft model, etc.) have already been verified since the turbocharger model suggested in this paper is based on the knowledge of the bearing and structural dynamics of crankshafts.

\section{CONCLUSIONS}

The designing of a modern turbocharger is a challenging area and requires extensive knowledge and prototype testing. The presented model provides engineers dealing with turbocharger design a powerful tool to minimize development time and costs. Even if this model has its limitations, based on the considered presumptions, it cannot replace proper testing. However, it can provide a general inside view of turbocharger rotor dynamics and help in understanding the influence of the studied parameters. Moreover, this tool can significantly decrease the development time, and of course this means that the development costs will also be reduced.

This model should be regarded as a basic step towards an advanced tool. Its further development aims at improving the bearing model, to better describe high speed applications.

\section{ACKNOWLED GEMENT}

This work is an output of NETME CENTRE PLUS research activities (project no. L01202) and is funded by the Ministry of Education, Youth and Sports under the National Programme for Sustainability I.

$\begin{array}{ll}\text { LIST OF NOTATIONS AND ABBREVIATIONS } \\ p \quad \text { pressure } \\ x, y & \text { coordinates } \\ h & \text { oil film gap height } \\ \eta & \text { dynamic viscosity } \\ \rho & \text { density } \\ u & \text { effective velocity } \\ R & \text { shell radius } \\ r & \text { journal radius } \\ e & \text { overall eccentricity } \\ e_{i} & \text { inner eccentricity } \\ e_{j} & \text { journal eccentricity } \\ e_{o} & \text { outer eccentricity } \\ \varphi & \text { angle around the journal axis } \\ B & \text { bearing diameter } \\ D & \text { bearing width } \\ \text { FDM } & \text { Finite Difference Method } \\ \text { FEM } & \text { Finite Element Method } \\ \text { MBS } & \text { Multi-Body System } \\ \text { TC } & \text { turbocharger }\end{array}$

\section{REFERENCES}

[1] NOVOTNÝ, P. Virtual Engine -A Tool for Powertrain Development. Brno: Brno University of Technology. Inaugural Dissertation. 2009.

[2] TIAN, L., W.J. WANG a Z.J. PENG. Nonlinear effects of unbalance in the rotor-floating ring bearing system of turbochargers. Mechanical Systems and Signal Processing. 2013, vol. 34, 1-2, s. 298-320. DOI: http://dx.doi. org/10.1016/j.ymssp.2012.07.017.

[3] SCHWEIZER, Bernhard, N. F. RIEGER, H. F. BLACK, Neville F. RIEGER a Charles B. THOMAS. Dynamics and stability of turbocharger rotors. Archive of Applied Mechanics. 2010, vol. 80, issue 9, s. 436-471. DOl: http://dx.doi. org/10.1007/978-3-642-48784-2_17.

[4] CASTRO, Helio Fiori de, Katia Lucchesi CAVALCA a Rainer NORDMANN. Whirl and whip instabilities in rotor-bearing system considering a nonlinear force model. Journal of Sound and Vibration. 2008, vol. 317, 1-2, pp. 273-293. DOI: http://dx.doi.org/10.1016/j.jsv.2008.02.047. 